\title{
Organizational political ideology, Host country institutions, and Impact on Employee outcomes
}

\author{
Dawn Yi Lin Chow, Xi Wen Chan and Evelyn Micelotta
}

\section{Introduction}

Much research in the area of non-market strategy has focussed on how companies attempt to deal with the external environment surrounding them. However, less research has focussed upon how the external nonmarket environment affects the ideologies and personal beliefs of senior managers within organizations, and how this could impact the organization internally. Cross-border merger and acquisition (M\&A) activity crossed the $\$ 1$ trillion mark in March 2018, the fastest it has ever reached that level, as the appetite for more global deals persists unabated (Platt \& Fontanella-Khan, 2018). A typical strategic motivation for companies to engage in M\&As is that, if synergies between the acquirer and the target firm are realized, the integration of the two firms will create more value for shareholders (Larsson \& Finkelstein, 1999; Stahl \& Voigt, 2008). Given such a strong rationale, M\&As are much sought-after.

In this paper, we suggest that cross-border M\&A integration efforts can be severely hindered when there is a mismatch between an important characteristic of the acquiring firmits organizational political ideology — and the local institutional environment in which the acquisition takes place. Organizational political ideology is defined as the prevailing beliefs among organizational members about how the social world, including micro worlds such as the organization, should operate (Gupta, Briscoe, \& Hambrick, 2017). It encompasses social expectations or even convictions about what outcomes are desirable and how they should be 
achieved (Gupta et al., 2017). Organizational political ideology is relatively stable; and unlike organizational culture, which is often developed for the new, combined entity in an M\&A (Nahavandi \& Malekzadeh, 1988), organizational political ideology cannot be contrived by top management wishing to engineer common employee mindsets amongst the merging organizations (cf. Gupta et al., 2017; Jost, Federico, \& Napier, 2009; Petrou et al., 2018). This is because political ideology is extra-organizational in the sense that it is a complex pastiche of outcomes resulting from a combination of top-down socialization processes due to familial, societal and other influences, as well as bottom-up psychological predispositions that reflect relational, epistemic and existential needs (Jost et al., 2009). For example, conservatives tend to be more tolerant of inequality, supportive of hierarchy, disciplinary toward rule violators and mistrustful of human nature (Jost et al., 2009; Tetlock, Vieider, Patil, \& Grant, 2013), and have a greater personal need for order and closure (the converse is true for liberals), and these effects tend to persist in different contexts. In sum, managers cannot "engineer" the political ideology of the body politic of the firm so easily, since, unlike organizational culture that can be developed amongst employees, political ideology comprises a relatively coherent, stable set of beliefs (Gupta et al., 2017; Bermiss \& McDonald, 2018).

Research on M\&As has grown significantly in recent years (Humphery-Jenner, Sautner, \& Suchard, 2017), as management scholars have been very much concerned with the challenges of these transactions, in particular cross-border ones, and how to increase their success rate (Morán \& Panasian, 2005). To date, research has primarily focused on assessing the benefits of M\&As, or their lack thereof. Studies have examined these transactions through various theoretical lenses, such as transaction cost theory (Barney \& Hesterly, 1996; Ireland, Hitt, \& Vaidyanath, 2002), the resource-based view of the firm (Eisenhardt \& Schoonhoven, 1996), and organizational learning theory (Kale, Singh, \& Perlmutter, 2000; Khanna, Gulati, \& Nohria, 1998), amongst others (for a review, see Shimizu, Hitt, Vaidyanath, \& Pisano, 2004). 
Yet, because the focus of analysis is typically on financial factors, researchers still have limited and selective knowledge on the influence of non-financial factors over the acquisition process (Hromei, 2014; Vaara, 2003), and in particular, their role in promoting or challenging the integration process and the achievement of desired outcomes.

A large body of research dating back from Jensen and Meckling's (1976) seminal work concentrates on manager-shareholder agency conflicts and the way these may affect equity valuations (John, Knyazeva, \& Knyazeva, 2015, p. 49; refer also to Petrou, Chow \& Procopiou, 2018). Although insightful, this economic approach does not recognize or assess the significance of the social concerns of key stakeholders (e.g., employees) for the successful implementation of the M\&A process. Critically, we address this limitation and suggest that mismatches in social expectations between organizations and their workforce are key reasons many mergers stutter (Graebner, Heimeriks, Huy, \& Vaara, 2017; Vaara \& Monin, 2010). For instance, Walmart's entry into Germany by acquiring Wertkauf and Interspar stores in Germany was "nothing short of a fiasco" (Knorr \& Arndt, 2003, p. i), as the company deemphasized unionization and, by doing so, ignored critical employee sensitivities.

In parallel to the strategic management literature on M\&As, a relatively more limited corpus of research has highlighted the importance of human resource (HR) issues in determining merger success or failure (c.f Morán \& Panasian, 2005; Piekkari, Vaara, Tienari, \& Säntti, 2005; Seo \& Hill, 2005). The number of studies that examine the influence of employees on the success of cross-border acquisitions is growing, but the focus has mostly been on cultural issues in post-merger integration, surmising that bridging areas of cultural incompatibility is the most challenging aspect of post-acquisition integration (Vaara, Sarala, Stahl, \& Björkman, 2012). Moreover, cultural issues are typically examined from the point of view of managers, rather than employees (Risberg, 2001) and national employment regulations are often ignored, even though they are extremely important for cross-border M\&A activities. 
If the acquiring firm's orientation toward labor is at odds with the host nation's employment regulation, the acquired firm's employees may face unexpected changes and experience a perception of breaches of trust in their organization and in their role expectations (Stahl, Chua, \& Pablo, 2012).

Drawing on a combination of the institutional and role theory perspectives, our article offers a multi-level theoretical model that introduces a new antecedent, i.e., the mismatch between the "organizational political ideology" of the acquiring firm and the employment protection regulations of the host country of the acquired firm, to better understand potential pitfalls of the post-M\&A process. To the extent that country-level institutional arrangements regarding employment protection are associated with social mindsets and expectations, matching organizational political ideology with local institutions is essential to avoid perceptions of corporate hypocrisy (Korschun, Aggarwal, Rafieian, \& Swain, 2016). Corporate hypocrisy may develop into HR issues (i.e., negative employee behaviors), that are likely to jeopardize the success of the post-merger implementation process. Our model illuminates a set of processes and mechanisms that may lead to negative employee outcomes, thereby advancing knowledge surrounding the failures of M\&As, or at the very least, their subpar outcomes.

Moreover, our model contributes by extending research on cross-border acquisitions by linking two perspectives of M\&A research, i.e., pre-announcement and post-acquisition integration (Angwin, 2007; Chatterjee, Lubatkin, Schweiger \& Weber, 1992; Gomes, Angwin,Weber, Tarba, 2013). Although our antecedent is based on acquirers' strategic choice ex-ante, our model focuses on employee outcomes post-acquisition. This is important, since post-acquisition employee outcomes are an important topic in the literature (Khan, Soundararajan, Wood \& Ahammad, 2017; van Knippenberg, van Knippenberg, Monden, \& de Lima, 2002; Younge, Tong \& Fleming, 2015), and yet, to our knowledge, no research has investigated the managerial implications of ignoring, ex-ante, target firm employees' social 
expectations as indicated by the dominant political ideology. We therefore highlight the critical role that managers can take to pre-emptively tackle issues that may lead to challenges, and even failure, of the acquisition; or if, despite mismatch, the acquisition must still be undertaken, employers may use our insights to compensate for the tendency of employees' negative behaviors by being fair about the process, thus ameliorating negative outcomes.

\section{Theoretical Framework: Beyond Cultural Incompatibilities}

Examining "cultural issues" in cross-border acquisitions has been essential and has importantly contributed to addressing concerns about the lack of research on non-financial factors. Indeed, cultural incompatibilities are the most often quoted reason for the failure of M\&As (Papadakis, 2007). For instance, research has examined how cultural differences impede acquisition integration (Buono \& Bowditch, 1989; Kostova, 1999; Olie, 1994; Sales \& Mirvis, 1984; Stahl \& Voigt, 2008), and how proper attention to these differences is necessary for successful integration (Birkinshaw, Bresman, \& Hakanson, 2000; Björkman, Stahl, \& Vaara, 2007; Schweizer, 2005; Uhlenbruck, 2004). However, culture-based explanations have become predominant, as "culture" is pointed to as the default culprit for most people integration problems within an organization.

We suggest that research on M\&A success or failure needs redirection and a renewed focus. Importantly, the cultural compatibility perspective provides insightful explanations for observed outcomes (Reus, 2012), but because of its roots in cross-cultural psychology, it does not take into account the fact that the stakeholders involved in a merger are also social actors. More generally, we consider all economic activities (M\&As included) to be embedded within an institutional context that motivates economic actors to seek legitimacy and social approval for their actions (Dacin, Oliver, \& Roy, 2007). Indeed, research in institutional theory has long demonstrated the impact that country-level institutions have on organizational practices, 
processes, and performance (Kostova, Roth, \& Dacin, 2008; Phillips, Tracey, \& Karra, 2009). For example, within a local market, foreign firms are at a disadvantage compared with domestic firms because of their liability of foreignness born out of institutional differences (Wu \& Salomon, 2017; Zaheer, 1995). As such, foreign firms need to build local legitimacy and gain the approval of host country constituents by adopting local practices (Kostova \& Roth, 2002; Scott, 1995). Critically, however, organizational policies and practices are not always consistent with the local institutions of the host country. Research on international acquisitions in China (e.g., Cooke, 2006), for instance, reveals that many issues - from misalignment of objectives, to undue intervention of the local government, to concerns over job security and labor disputes - may be responsible for cross-border acquisitions not yielding the desired benefits.

Strategic management scholars have recently emphasized the role that political ideology plays in shaping corporate practices and outcomes (Briscoe, Chin, \& Hambrick, 2014; Gupta et al., 2017). Research has shown how organizational political ideology impacts firm decisions regarding corporate social responsibility initiatives (Briscoe et al., 2014; Gupta et al., 2017), pay egalitarianism within top management (Chin \& Semadeni, 2017), the gender gap in wages (Briscoe \& Joshi, 2016), as well as the allocation arrangements of resources to different firm subunits (Gupta, Briscoe, \& Hambrick, 2018). However, to our knowledge, this important concept has not been used to better understand processes and outcomes of cross-border M\&As and, in particular, its potential effect on negative employee behaviors.

Specifically, with regard to M\&A research, we posit that the acquiring firm should be sensitive to issues arising from entering a country in which local institutions are at odds with the firm's espoused political ideology. In addition, we focus on one specific local institution the employment protection regulations in the host country. Although there is a wide array of economic, political, regulatory and cultural institutions that could be salient in the M\&A 
integration process, for example, safety (Regnér \& Edman, 2014), or intellectual property rights regulations (Oxley, 1999), employment protection regulations are particularly central in M\&A transactions. Employment practices are a contentious issue in many takeovers and mergers (Dessaint, Golubov, \& Volpin, 2017), not just because of the approving government entity's possible rejection of the deal, but also because labor disputes are a highly relevant issue to target firm employees, who worry about retrenchment or other unfavorable terms in the agreement. More broadly, employment protection regulations are an indicator of a society's priorities (Aguilera \& Jackson, 2003) and reflect important ideological trends. For instance, less flexible employment protection regulations are associated with societal mindsets that favor employees' rights and equality (John et al., 2015; Petrou et al., 2018).

Hence, we theorize that the acquired company employees' mindset on employee rights, and more broadly the host country stakeholders' expectations and interests, will interact in significant ways with organizational political ideology ${ }^{1}$. That is, to the extent that a more stringent employment protection regime indicates a within-country mindset in favor of labor rights, an acquirer with a more conservative ideology that emphasizes personal accountability and greater tolerance of inequality would be deemed a poorer fit. In particular, we integrate the role theory perspective at the organizational and individual levels of analysis (Biddle, 1986; Katz \& Kahn, 1966, 1978; Hage \& Marwell, 1968; Marwell \& Hage, 1970; Merton, 1957), to suggest that the mismatch between an acquiring organization's political ideology and local employment regulations systems may lend itself to perceptions of corporate hypocrisy $y^{2}$. We

\footnotetext{
${ }^{1}$ We assume that local firms align with the institutional arrangements of the host country. Institutional theory supports the contention that organization become isomorphic with their environment, in that they align with their environment's predominant expectations and beliefs to acquire and maintain legitimacy. It is true that heterogeneity is possible and that organizations may deviate; however, if institutional arrangements are dominant and not contested, organizations that deviate suffer from social penalty.

${ }^{2}$ Perceptions of corporate hypocrisy can arise from multiple sources, for example, when a company engages in greenwashing when, in fact, its products are not environmentally friendly. Notably, such perceptions may arise even when there is a match between the acquirer's political ideology and host country institutions. However, in this paper we focus on corporate hypocrisy perceptions that arise when there is a mismatch. Our framework posits mismatch as a new antecedent that has not been considered in M\&A research, and thus it can help predict integration problems ex-ante, before a costly merger decision takes place.
} 
theorize the effects of such mismatch on employee attitudes and behavioral outcomes to understand the mechanisms through which such processes can hinder integration efforts. Role theory, with its underpinnings in social psychology and interpersonal sociology, can offer insights on the cognitive and social processes that undergird the interactions between the organization and employees, which are at the core of M\&A processes.

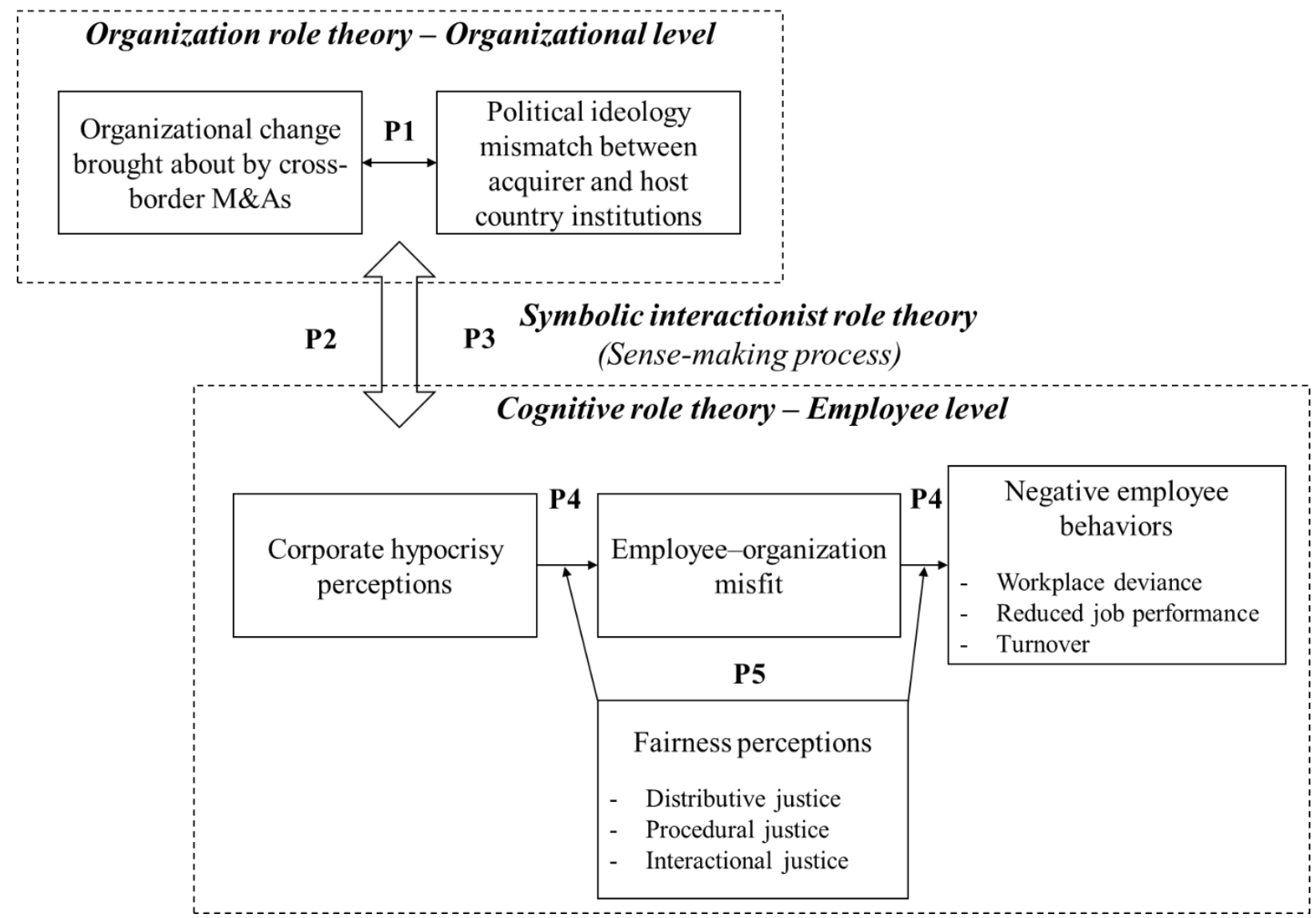

Figure 1: A theoretical framework of political ideology-employment regulations mismatch in cross-border M\&As and its effects on employee outcomes.

Figure 1 illustrates our theoretical framework. At the organizational level, the changes brought about by an M\&A are likely to reveal the mismatch between the acquirer's political ideology and the employment protection regulations institutions of the host country. At the level of the employees' cognition, this mismatch may result in the perception of corporate 
hypocrisy and employee-organization misfit, which subsequently impacts employee behaviors (e.g., deviant workplace behaviors, reduced job performance and turnover). Fairness perceptions are expected to moderate the relationship leading from corporate hypocrisy perception to employee-organization misfit, and finally, negative employee behaviors.

The following section elaborates our framework and offers propositions. We conclude the paper with a discussion of its contributions to the study of international business.

\section{Political Ideology- Local Institutions Mismatch and Corporate Hypocrisy}

\section{Perceptions}

Political ideology - host country institutions mismatch occurs when a company enters institutional contexts where host country institutions are at odds with the firm's political stance in the home country. In the case of a conservative-leaning firm entering a host country with strong employment protection regulations, the different relevant audiences may heavily discount the firm's professed intentions, upon acquisition, to ensure protection of employee rights. When there is a disjuncture between a company's claims and its manifest behavior, perceptions of corporate hypocrisy emerge (Korschun et al., 2016). Wagner, Lutz and Weitz (2009) define corporate hypocrisy as a consumer's "belief that a firm claims to be something it is not." This definition can be fruitfully extended to understand employee sentiment. That is, employees of the targeted company may be highly skeptical of the intentions of a conservativeleaning acquirer, since they believe that conservative-leaning organizations tend to value efficiency and performance-related economic rewards (Jost, 2006) over individual privileges and employee rights.

With such perceptions of corporate hypocrisy, an "us-versus-them" mentality is likely to be triggered, and the employees of the target firm would view the acquisition process, already inherently contentious, even more negatively. For instance, during the pre-integration stage, 
despite the acquirer's ostensible promises, target company employees' mistrust may arise with respect to the acquirer's intentions regarding layoffs and cuts in benefits. This mistrust may be further exacerbated post-merger, once the acquirer actually carries out its restructuring plans. On the other hand, if there is a match between the institutional context and the acquirer's political ideology, the alignment between the acquirer and target employees in terms of shared values and expectations may reduce the likelihood of deviant workplace outcomes. For instance, liberal-leaning organizations can more easily gain legitimacy in local environments with more inflexible employment protection regulations, because of a closer match between the values of the firm political ideology and the ideological stances reflected in local regulatory policies. The liberal ideology may act as a catalyst in accepting different and more lenient labor practices within the target organization, thus safeguarding social unity within the merged entity. Furthermore, liberal ideology's symbolic value may be mobilized to signal compatibility of beliefs on labor rights within the target organization, thus assuaging the concerns of employees, and thereby building moral standing with them.

In the next section, we summarize the role theory perspective. Thus far, theoretical explanations of psychological contract breach and organizational justice perceptions have typically been used to explain employees' experiences and responses to cross-border M\&As (see Bellou, 2006; Cho, Park, \& Dahlgaard-Park, 2017; Gomes, Mellahi, Sahadev, \& Harvey, 2017). We show how role theory provides an overarching, integrative framework for understanding cross-border M\&As, and in particular its influence on employee behavior.

\section{Introducing role theory to theorize the impact of political ideology- institution mismatch on employee behaviors}


Table 1 summarizes the three streams of work which we draw on: 1) organizational role theory (Kahn, Wolfe, Quinn, Snoek, \& Rosenthal, 1964; Katz \& Kahn, 1966), 2) cognitive role theory (Burke, 1991; DiMaggio, 1997; Moreno, 1934; Stryker, 1991), and 3) sensemaking (embedded within symbolic interactionist role theory) (Blumer, 1962; Mead, 1934; Stryker, 1987; Stryker \& Statham, 1985).

\section{Organizational role theory}

Organizational role theory concerns how roles are influenced by hierarchical positions and norms, reflecting both the official demands of the organizations, and informal, unspoken group norms (Biddle, 1986). Within an organization, there are multiple sources of expectations. Expectations may stem from the official demands of the organization, the specific requests of an immediate supervisor, and/or the pressures of co-workers or informal groups. As noted earlier, the changes brought about by the cross-border M\&A process may lead to perceptions of corporate hypocrisy and exacerbate a sentiment of employee-organization misfit, when the positive role expectations, social norms and perceptions that employees hold of their organization are violated (Sutton, 1991). Indeed, organizational role theory suggests that, for existing employees in any organization, "the more consensus they have on the expectations for their own and the others' positions, the more gratification members of a group will derive from the occupancy of their positions" (Gross, Mason, \& McEachern, 1958, p. 213).

Table 1: A summary of role theory perspectives

\begin{tabular}{|l|c|c|}
\hline $\begin{array}{l}\text { Role theory } \\
\text { perspectives }\end{array}$ & Seminal works & Summary of key ideas \\
\hline $\begin{array}{l}\text { Organizational role } \\
\text { theory }\end{array}$ & $\begin{array}{c}\text { (Hage \& Marwell, } \\
1968 ; \text { Kahn et al., } \\
1964 ; \text { Katz \& } \\
\text { Kahn, 1966, 1978; }\end{array}$ & $\begin{array}{c}\text { Social structures are conceived as formal } \\
\text { organizations, which are pre-planned, task- } \\
\text { oriented, and hierarchical }\end{array}$ \\
\hline
\end{tabular}




\begin{tabular}{|c|c|c|}
\hline & $\begin{array}{l}\text { Marwell \& Hage, } \\
\text { 1970) }\end{array}$ & $\begin{array}{l}\text { Roles in organizations are assumed to be associated } \\
\text { with identified social positions and to be } \\
\text { generated by normative expectations, but norms } \\
\text { may vary among individuals and may reflect both } \\
\text { the official demands of the organizations and the } \\
\text { pressures of informal groups } \\
\text { Actors accept and take on roles that are conferred } \\
\text { upon them by their employers when they accept } \\
\text { an employment position }\end{array}$ \\
\hline $\begin{array}{l}\text { Symbolic } \\
\text { interactionist role } \\
\text { theory } \\
\text { (Sensemaking) }\end{array}$ & $\begin{array}{l}\text { (Blumer, 1962; } \\
\text { Mead, 1934; } \\
\text { Stryker, 1987; } \\
\text { Stryker \& Statham, } \\
\text { 1985) }\end{array}$ & $\begin{array}{l}\text { Social structures are conceived as shared norms } \\
\text { associated with social positions } \\
\text { Roles are neither fixed nor prescribed; they reflect } \\
\text { norms, attitudes, contextual demands, negotiation, } \\
\text { and the evolving definition of the situation as } \\
\text { understood by the actors } \\
\text { Actors understand and interpret their own and } \\
\text { others' conduct through social interaction }\end{array}$ \\
\hline $\begin{array}{l}\text { Cognitive role } \\
\text { theory }\end{array}$ & $\begin{array}{l}\text { (Burke, 1991; } \\
\text { DiMaggio, 1997; } \\
\text { Moreno, 1934; } \\
\text { Stryker, 1991) }\end{array}$ & $\begin{array}{l}\text { Social structures are conceived through } \\
\text { perceptions of group norms and expectations of } \\
\text { roles and behaviors } \\
\text { Roles are conceptualized as a network of } \\
\text { associations and sustained by cognitive structures } \\
\text { that simultaneously construct and reproduce the } \\
\text { social structures } \\
\text { Actors enact roles through interpreting the } \\
\text { associations between role expectations and } \\
\text { behaviors }\end{array}$ \\
\hline
\end{tabular}

Organizational role theory also suggests that discrepancies in expectations produce tension, dissatisfaction, anxiety, confusion, and indecision, as well as diminished selfperceptions of competence and effectiveness (Kahn et al., 1964). Also, Korschun et al. (2016) note that interacting with someone who is considered hypocritical is distressing because it threatens self-schemas and suggests an intention to create a false impression towards others. Thus, feelings of insecurity could potentially emerge in a relationship when interpersonal deception is detected (Gillath, Sesko, Shaver, \& Chun, 2010; Korschun et al., 2016). Extending 
these insights to employee perceptions of the organization, when employees interact with an organization they deem hypocritical, their view of themselves as coherent and moral people is threatened. They may also face role conflict as their own sense of self as moral and ethical people could be challenged (Batson, Thompson, Seuferling, Whitney, \& Strongman, 1999).

Critically, major organizational changes such as cross-border M\&As tend to modify employees' perceptions of, and reactions to, the employment relationship (Zhao, Wayne, Glibkowski, \& Bravo, 2007), and trigger psychological contract re-evaluations (Chaudhry, Coyle-Shapiro, \& Wayne, 2011). In particular, individuals may perceive the merger with an acquirer that has a political ideology opposed to the ethos of host country institutions as a breach of the psychological contract. In these conditions, employees may experience a sense of violation (Robinson \& Morrison, 2000), characterized by “disappointment, frustration, and distress stemming from the perceived failure to receive something that is both expected and desired" (Morrison \& Robinson, 1997, p. 231). At a deeper level, psychological contract violation also leads to feelings of betrayal, anger and bitterness due to broken work-related promises (Morrison \& Robinson, 1997; Robinson \& Morrison, 2000). We therefore propose:

Proposition 1. In a cross-border M\&A, the organizational change brought about in the implementation process (e.g., changing social positions, expectations, norms and demands) reveal to the employees of the acquired organization whether there is a fit or mismatch between the political ideology of the acquiring organization and the host country institutional context.

Proposition 2. If there is political ideology mismatch between the acquirer and the host country institutional context, the employees of the acquired organization perceive the acquirer as a "corporate hypocrite" and the cross-border M\&A as a violation of their psychological contract with the organization. 


\section{Symbolic interactionist role theory (sensemaking)}

Theories of sensemaking offer an alternative path to the perception of corporate hypocrisy and misfit. Sensemaking is a key construct in symbolic interactionist role theory that focuses on how employees in organizations are constantly trying to make sense of their roles and the flow of activities in which they find themselves (Weick, 1995). In situations such as an organizational change due to a cross-border M\&A, there may be explicit efforts to engage in sensemaking as employees perceive the current state of the world to be different from the expected state of the world (i.e., changing role expectations) (Weick, Sutcliffe, \& Obstfeld, 2005). To make sense of the organizational change and its uncertainty, employees tend to first look for reasons that will enable them to resume their day-to-day activities, tasks and job scopes within the organization. These "reasons" derive from social structures, organizational role expectations, and the shared norms and traditions in the organization (Biddle, 1986; Weick et al., 2005). If resumption of the "normal course of action" is problematic, then employees' sensemaking is biased either toward identifying an alternative course of action or toward further sensemaking (Weick et al., 2005, p. 405).

We thus propose that sensemaking is a core element of the target firm employees' calculus, with regards to the impact of the M\&A on their organization that can prevent the perception of corporate hypocrisy. Other than being an affective reaction, psychological contract violation can be a sensemaking process, whereby the importance attached to psychological contract breach is influenced by a range of contextual factors such as employees' expectations and attributions about the acquirer's behavior, their own perceived losses and employment alternatives, the acquirer's ideology, and procedural justice (Conway \& Briner, 2009; Robinson \& Morrison, 2000). 
As Morrison (1994, p. 355) puts it, "The psychological contract does not just change over time; change itself modifies the contract...Furthermore, during times of change, new expectations are built and reinforced." We further argue that psychological contract violation is a fluid, interactive process in which employees interpret changes and meanings through social interaction. Drawing on the symbolic interactionist perspective of role theory (see Biddle, 1986; Mead, 1934; Stryker, 1987), we focus on the ways in which employees interpret and understand their roles and that of others, as well as institutional norms, social positions, general attitudes and behaviors, contextual demands and negotiations through informal interaction with other members. Symbolic interactionist role theory posits that social interaction is a sensemaking process in which meanings evolve and change over the course of the interaction (Martin \& Wilson, 2005). Specifically, roles are viewed as fluid, emerging and evolving out of the interactional process. By "taking the role of the other" (referred to as "roletaking”), people are able to imagine how others will interpret their behavior. Individuals may also take the role of a "generalized other" (e.g., a co-worker or spouse) by imagining how specific groups (e.g., students, managers, or family members) may respond to their behavior.

When applied to our research context, employees may take the perspective of their spouses or family members to decide whether and how to continue working for an organization with an ideology that is inconsistent with their own personal beliefs. Through role-taking, employees are then able to understand why others' views may differ from their own and decide on a course of action manifested in the form of increased or decreased levels of organizational citizenship behavior, organizational commitment, or job performance following the crossborder M\&A.

Proposition 3. Following the political ideology mismatch between the acquirer and the acquired organization, employees may engage in interpreting and understanding their 
own roles and that of others (i.e., sensemaking), to re-evaluate their relationship with the organization and reject the perception of corporate hypocrisy.

\section{Cognitive Role Theory}

As noted earlier, when there is a political ideology mismatch between the acquirer and the acquired organization, the employee may perceive corporate hypocrisy, breach of psychological contract and misfit with the organization. Cognitive role theory is helpful to theorize the relationship between perception of discrepancy in role associations and behavior (Stryker, 1991). The traditional role theory perspectives (e.g., functional, structuralist, symbolic interactionist and organizational) tend to emphasize behavior over cognition, hence there is little understanding of the underlying process through which roles influence perception, cognition and behavior within the individual (Biddle, 1986). Cognitive role theory was developed based on cognitive social psychology and focuses attention on the process through which social conditions give rise to expectations, the assessment of these expectations and the impact of these expectations on social conduct (Markus \& Zajonc, 1985).

Based on cognitive role theory, perceptions of breach may result in attitudinal and behavioral outcomes such as turnover intentions, actual turnover, in-role performance and organizational citizenship behavior (Morrison \& Robinson, 1997). Bordia, Restubog, and Tang (2008) have argued that psychological contract violation is essentially an affective event that causes employees to experience an emotionally charged affective reaction. Therefore, psychological contract breach elicits negative work attitudes, such as reduced affective commitment, job satisfaction and increased turnover intentions. Many studies have also found associations between employee perceptions of psychological contract violation and reduced employee contributions toward their organization, such as decreased organizational commitment and organizational citizenship behaviors (Bal, De Lange, Jansen, \& Van Der 
Velde, 2008; Zhao et al., 2007). This is because, in the face of psychological contract violation, employees seek to restore a sense of equity by rebalancing their contributions (Bal et al., 2008). The opposite is also true. When employees perceive fit, they tend to develop positive attitudes toward change and expect benefits to accrue from such change (Caldwell, Herold, \& Fedor, 2004).

We can also expect that changing role expectations brought about by the cross-border M\&A change will negatively affect employees' job performance due to job stress and uncertainties (physiological and psychological reactions). This chain of process may eventually lead to turnover as employees decide to leave the organization.

Proposition 4. Employees who experience organization misfit due to perceptions of corporate hypocrisy are prone to display negative reactions such as workplace deviance, reduced job performance, and turnover.

\section{The Influence of Fairness Perceptions}

Our model invokes role theory as an overarching framework to explain the relationship between M\&A-related organizational change and employee outcomes. In order to understand the potential impact of perception of corporate hypocrisy on adverse employee outcomes, it is useful to consider the insights of organizational justice theory. Shared norms, and their perceived violation in the context of M\&As, form the basis of the link between fairness perceptions and employee behaviors. We consider the three types of fairness perceptions: distributive justice, procedural justice and interactional justice.

The first type of fairness perception is distributive justice, which is the fairness of outcomes received compared to an individual's standard of fairness (Adams, 1965). In strategic alliances, as in M\&As, the outcomes that are distributed are primarily group-related and deal with resource allocation between the firms involved in the M\&A (Luo, 2007). In the context 
of M\&As, distributive justice is defined as the extent to which the resource allocation at the level of an employee's group of reference (e.g., his or her department) is perceived as fair. Distributive justice plays an important role in promoting cooperative behaviors, especially in contexts of drastic change such as an M\&A (Melkonian, Monin, \& Noorderhaven, 2011). In their study, Melkonian et al. (2011) also found that when employees were first confronted with information about M\&A outcomes before having access to information about the decisionmaking procedure, the impact of distributive justice perceptions on employees' attitudes and behaviors was strong. When employees perceive that distributive justice is present, they view their efforts and devotion as being compensated sufficiently. Consequently, their satisfaction with and loyalty toward the organization are likely to increase. Conversely, when employees feel that the decision outcomes of the M\&A on issues such as nominations for positions, layoffs, or office relocations are not in their favor as compared to their department mates in the new, combined entity, they may feel singled out and particularly aggrieved. This would exacerbate the impact on adverse employee outcomes.

The second type of fairness perception is procedural justice, which is the fairness of procedures used to determine outcomes (Thibaut \& Walker, 1975). Fair and consistent decision-making is crucial in complex M\&A processes, especially in re-organization and restructuring. However, because of its "acquiring" role, the acquirer is likely to have the upper hand in terms of dominance, and in terms of shaping the eventual merged organization (van Knippenberg et al., 2002). This may not bode well for the target company employees' perceptions of "fair" decision making in their favor. Indeed, the difference in organizational dominance plays an important role in determining how the merger is experienced, with the dominance asymmetry working to communicate to the employees of the dominant organization that the merged organization is "their" organization, whereas it may communicate to the employees of the dominated partner that "they are now a member of the other organization" 
(van Knippenberg et al., 2002). Given this perception that the invading conqueror has the upper hand in negotiations, and even during the integration process, we suggest that it is unlikely that employees will believe they have been dealt with fairly during the decision-making process. In addition, with regard to our context of institutional mismatch, the employees of the acquirer may perceive the target company as the "dominated" entity, and one that does not share key values relating to fair remuneration and employment rights. Therefore, employees of the target company may be labeled as lazy and privileged, and considered the out-group. An acquirer might not be inclined to deal fairly with an unequal partner with social values opposed to their political ideology. As such, we also propose that procedural injustice will strengthen the positive relationship between corporate hypocrisy perceptions and adverse employee outcomes.

The third and last fairness perception is interactional justice, which refers to how the organizational members are treated by those responsible for determining outcomes and procedures (Tyler \& Bies, 1990). Interactional justice can be split into two distinct types of justice - interpersonal justice and informational justice (Greenberg, 1993). Interpersonal justice refers to the fairness of interpersonal treatment rendered during the enactment of procedures and distributions of outcomes, and informational justice refers to the fairness of explanations and information (specifically, in terms of the accuracy and timeliness of the information provided) (Colquitt, 2001). During the integration process of the merger, if employees of the acquired company perceive that their opinions are not adequately heard (interactional injustice), or that they are the last to be "in the know" regarding important decisions, the positive relationship between corporate hypocrisy perceptions and adverse employee outcomes could also be intensified. Taken together, we thus posit that: 
Proposition 5. Perceptions of lack of distributive justice, procedural justice, and interactional justice strengthen the positive relationship between corporate hypocrisy perceptions and negative employee outcomes.

\section{Discussion and Contributions}

Overall, our theoretical model advances research on cross-border M\&As by offering a novel set of processes and mechanisms that explain the often disappointing outcomes of these transactions. Whereas extant research has predominantly focused on cultural differences, often from the point of view of managers, we draw on an institutional perspective to suggest that alignment between characteristics of the acquiring organization (i.e., the acquirer's organizational political ideology) and the institutional environment of the host country (i.e., employment regulations) is a key antecedent. Moreover, we draw on three cognate role theories at different levels of analysis to theorize the cognitive mechanisms through which this organizational level mismatch leads to negative employee outcomes. By doing so, we also show the usefulness of giving more attention to the perceptions of employees and HR issues in research on cross-border M\&As.

Our research framework offers an important theoretical extension of the emerging literature on organizational political ideology (Bermiss \& McDonald, 2018; Briscoe et al., 2014; Briscoe \& Joshi, 2016; Carnahan \& Greenwood, 2018; Chin \& Semadeni, 2017; Chin, Hambrick \& Trevino, 2013; Gupta et al., 2017; Gupta et al., 2018). Understanding how political ideology influences organizational processes and outcomes is a burgeoning stream of work. To our knowledge, there has been no application of this concept in the published literature on cross-border M\&As and their potential impact on the perceptions and behaviors of the employees of the acquired firm. We contribute to this burgeoning research by theorizing how the political beliefs of an acquirer interact with local institutionalized beliefs and practices 
to shape the processes and outcomes of an M\&A. This is an important contribution, since political ideologies drive important decisions in organizations (Briscoe \& Joshi, 2016; Carnahan \& Greenwood, 2018; Gupta et al., 2017), but the extensiveness of its influence is still not well understood.

Critically, our model incorporates a still not-well-understood concept - corporate hypocrisy - to connect the evidence of mismatch between political ideology and host country institutions at the organizational level with the cognitive level of employees. Studies of corporate hypocrisy have emerged in marketing research on consumer behavior (Korschun et al., 2016; Marín, Cuestas, \& Román, 2016; Skarmeas \& Leonidou, 2012; Wagner et al., 2009), but its potential for understanding organizations is still mostly untapped. In our framework, we have shown the insights that can be yielded when corporate hypocrisy is used to predict changes in employees' perceptions and role expectations. The fact that people tend to bestow human characteristics onto companies (Korschun et al., 2016) adds support to our role theory framework. In the eyes of employees, the acquirer is bestowed the human characteristic of hypocrisy.

By offering a framework that theorizes the effects of macro-regulatory institutions on micro-level behavior and outcomes, we also contribute to bridging the gap between macro and micro levels in the literature (Dacin et al., 2007, Dacin, Beal, \& Ventresca, 1999; Kostova et al., 2008). Specifically, we extend the literature on the microfoundations of institutional theory (Felin, Foss, \& Ployhart, 2015; Powell \& Rerup, 2017) by introducing role theory to capture the microfoundations of social interactions and dynamics in the context of cross-border M\&As (Orlandi, Shemla, \& Heugens, 2018). Insights from our framework on the micro, meso, and macro levels of social interactions, coupled with the extensive research on cultural issues, should be able to raise the predictive power of M\&A research. 
Finally, our integrated framework has practical usage from a managerial standpoint. The framework suggests that the violation of role expectations may have important consequences, as the managers of the acquiring firm will face headwinds from the employees of the acquired firm. As such, to avoid problems ex-post, managers of acquiring firms should consider the match between their organizational political ideology and the employment protection institutions of the host country. The advantage of incorporating role expectations in the decision-making process is that potential integration problems can be assessed ex-ante. This opportunity confers a great advantage over the cultural compatibility perspective and its suggestion to foster cultural integration, as managers have little means of properly assessing the target company's organizational culture prior to the completion of the transaction (McIntyre, 2004; Teerikangas \& Very, 2006). Thus, our research directs managers' attention to organization-institutions (mis)match, beyond cultural or financial explanations.

Despite their knowledge of mismatching ideologies, managers may still choose to pursue the acquisition. In this scenario, our model suggests that ensuring fairness can attenuate the perception of corporate hypocrisy. The insight for managers is that, providing justice-relevant information relating to both the distributive and procedural aspects, and also increasing the level of interactional justice, should mitigate negative employee outcomes (Melkonian et al., 2011). A do-nothing approach may be the least appropriate, because resumption of the "normal course of action" (Weick et al., 2005, p. 405) may prove problematic for employees if they are unable to make sense of the changes. In such a context, managers would benefit from anticipating employees' sensemaking struggles and being sensitive in terms of managing employees' justice perceptions.

Our proposed model opens up directions for future research. Moving forward, we encourage future scholars to expand our framework by considering additional elements, as follows. First, we did not consider employees' individual differences, such as their willingness 
to cooperate, adaptability to change, and their potential to influence the relationships we theorize. Employees who are more open and adaptable may welcome the changes brought about by a cross-border M\&A and react positively, even if they experience misfit. Second, future examinations of the different moderating influence of fairness perceptions could yield more nuanced findings. Some studies on the three types of fairness perceptions (e.g., Melkonian et al., 2011) indicate that distributive and procedural justice are more strongly related to reactions towards the organization, while interactional justice is more strongly related to reactions towards the supervisor. We thus suspect that corporate hypocrisy perceptions may be ameliorated to a greater extent by distributive and procedural justice perceptions than by interactional justice. These are tentative suggestions, but future empirical studies could further examine the differentiated effects of each of these moderators.

Finally, as Sinkovics et al. (2011) pointed out, cross-border M\&As are highly emotional events, but research on their emotional aspects is still in its infancy. Scholars have begun to examine potential differences in the role emotions play in different industries, e.g., consumercentric versus manufacturing (Knight, Menges \& Bruch, 2018). Based on this observation, our proposed relationships might be differently affected when the two firms involved in the M\&A belong to different industries. Future research may expand on the role of emotions when examining the impact of cross-border M\&As on employees. In sum, our model provides a first step to motivate researchers to embark on research in these new, fruitful directions.

\section{References}

Aguilera, R. V., \& Jackson, G. 2003. The cross-national diversity of corporate governance: Dimensions and determinants. Academy of Management Review, 28(3): 447-465.

Angwin, D. N. 2007. Mergers and acquisitions. Oxford, UK: Blackwell.

Bal, P. M., De Lange, A. H., Jansen, P. G., \& Van Der Velde, M. E. 2008. Psychological contract breach and job attitudes: A meta-analysis of age as a moderator. Journal of Vocational Behavior, 72(1): 143-158. 
Barney, J. B., \& Hesterly, W. 2006. Organizational economics: Understanding the relationship between organizations and economic analysis. In S. Clegg, C. Hardy \& W. R. Nord (Eds), The SAGE handbook of organization studies: 111-148. London: Sage.

Batson, C. D., Thompson, E. R., Seuferling, G., Whitney, H., \& Strongman, J. A. 1999. Moral hypocrisy: appearing moral to oneself without being so. Journal of Personality and Social Psychology, 77(3): 525-537.

Bellou, V. 2006. Psychological contract assessment after a major organizational change: The case of mergers and acquisitions. Employee Relations, 29(1): 68-88.

Bermiss, Y. S., \& McDonald, R. 2018. Ideological misfit? Political affiliation and employee departure in the private-equity industry. Academy of Management Journal, advance online publication 27 February. doi: 10.5465/amj.2016.0817.

Biddle, B. J. 1986. Recent developments in role theory. Annual Review of Sociology, 12(1): 67-92.

Birkinshaw, J., Bresman, H., \& Håkanson, L. 2000. Managing the post-acquisition integration process: How the human integration and task integration processes interact to foster value creation. Journal of Management Studies, 37(3): 395-425.

Blumer, H. 1962. Human society as symbolic interaction. In A. M. Rose (Ed), Human behavior and social process: 179-192. Boston, MA: Houghton Mifflin.

Björkman, I., Stahl, G. K., \& Vaara, E. 2007. Cultural differences and capability transfer in cross-border acquisitions: The mediating roles of capability complementarity, absorptive capacity, and social integration. Journal of International Business Studies, 38(4): 658-672.

Bordia, P., Restubog, S. L. D., \& Tang, R. L. 2008. When employees strike back: investigating mediating mechanisms between psychological contract breach and workplace deviance. Journal of Applied Psychology, 93(5): 1104-1117.

Braguinsky, S., \& Hounshell, D. A. 2016. History and nanoeconomics in strategy and industry evolution research: Lessons from the Meiji-Era Japanese cotton spinning industry. Strategic Management Journal, 37(1): 45-65.

Briscoe, F., Chin, M. K., \& Hambrick, D. C. 2014. CEO ideology as an element of the corporate opportunity structure for social activists. Academy of Management Journal, 57(6): 1786-1809.

Briscoe, F., \& Joshi, A. 2017. Bringing the boss's politics in: Supervisor political ideology and the gender gap in earnings. Academy of Management Journal, 60(4): 1415-1441.

Buono, A. F., \& Bowditch, J. L. 1989. The human side of mergers and acquisitions. San Francisco, CA: Jossey-Bass Publishers.

Burke, P. J. 1991. Attitudes, behavior, and the self. In J. A. Howard \& P. L. Callero (Eds), The self-society dynamic: Cognition, emotion, and action: 189-208). Cambridge: Cambridge University Press.

Caldwell, S. D., Herold, D. M., \& Fedor, D. B. 2004. Toward an understanding of the relationships among organizational change, individual differences, and changes in person-environment fit: A cross-level study. Journal of Applied Psychology, 89(5): 868-882.

Carnahan, S., \& Greenwood, B. N. 2018. Managers' political beliefs and gender inequality among subordinates: Does his ideology matter more than hers?. Administrative Science Quarterly, 63(2): 287-322.

Chatterjee, S., Lubatkin, M. H., Schweiger, D. M., \& Weber, Y. 1992. Cultural Differences and Shareholder Value in Related Mergers: Linking Equity and Human Capital. Strategic Management Journal, 13: 319-334.

Chaudhry, A., Coyle-Shapiro, J. A. M., \& Wayne, S. J. 2011. A longitudinal study of the impact of organizational change on transactional, relational, and balanced 
psychological contracts. Journal of Leadership \& Organizational Studies, 18(2): 247259.

Chin, M. K., \& Semadeni, M. 2017. CEO political ideologies and pay egalitarianism within top management teams. Strategic Management Journal, 38(8): 1608-1625.

Chin, M. K., Hambrick, D. C., \& Treviño, L. K. 2013. Political ideologies of CEOs: The influence of executives' values on corporate social responsibility. Administrative Science Quarterly, 58(2): 197-232.

Cho, I., Park, H., \& Dahlgaard-Park, S. M. 2017. The impacts of organisational justice and psychological resilience on employee commitment to change in an M\&A context. Total Quality Management \& Business Excellence, 28(9-10): 989-1002.

Colquitt, J. A. 2001. On the dimensionality of organizational justice: A construct validation of a measure. Journal of Applied Psychology, 86(3): 386-400.

Conway, N., \& Briner, R. B. 2009. Fifty years of psychological contract research: what do we know and what are the main challenges. In G. P. Hodgkinson, \& J. K. Ford (Eds), International review of industrial and organizational psychology (Vol. 24): 71-130. Chichester, UK: Wiley-Blackwell.

Cooke, F. L. 2006. Acquisitions of Chinese state-owned enterprises by multinational corporations: Driving forces, barriers and implications for HRM. British Journal of Management, 17(S1): S105-S121.

Dacin, M. T., Beal, B. D., \& Ventresca, M. J. 1999. The embeddedness of organizations: Dialogue \& directions. Journal of Management, 25(3): 317-356.

Dacin, M. T., Oliver, C., \& Roy, J. P. 2007. The legitimacy of strategic alliances: An institutional perspective. Strategic Management Journal, 28(2): 169-187.

Dessaint, O., Golubov, A., \& Volpin, P. 2017. Employment protection and takeovers. Journal of Financial Economics, 125(2): 369-388.

DiMaggio, P. 1997. Culture and cognition. Annual Review of Sociology, 23(1): 263-287.

DiMaggio, P., \& Powell, W. W. 1983. The iron cage revisited: Collective rationality and institutional isomorphism in organizational fields. American Sociological Review, 48(2): 147-160.

Dunbar, R. L., \& Ahlstrom, D. 1995. Seeking the institutional balance of power: Avoiding the power of a balanced view. Academy of Management Review, 20(1): 171-192.

Eisenhardt, K. M., \& Schoonhoven, C. B. 1996. Resource-based view of strategic alliance formation: Strategic and social effects in entrepreneurial firms. Organization Science, 7(2): 136-150.

Felin, T., Foss, N. J., \& Ployhart, R. E. 2015. The microfoundations movement in strategy and organization theory. The Academy of Management Annals, 9(1): 575-632.

Gillath, O., Sesko, A. K., Shaver, P. R., \& Chun, D. S. 2010. Attachment, authenticity, and honesty: Dispositional and experimentally induced security can reduce self-and otherdeception. Journal of Personality and Social Psychology, 98(5): 841-855.

Gomes, E, Angwin, D, Weber, Y \& Tarba, S. 2013. Critical success factors through the mergers and acquisitions process: Revealing pre- and post- M\&A connections for improved performance. Thunderbird International Business Review, 55(1): 13-35.

Gomes, E., Mellahi, K., Sahadev, S., \& Harvey, A. 2017. Perceptions of justice and organisational commitment in international mergers and acquisitions. International Marketing Review, 34(5): 582-605.

Graebner, M. E., Heimeriks, K. H., Huy, Q. N., \& Vaara, E. 2017. The process of postmerger integration: A review and agenda for future research. Academy of Management Annals, 11(1): 1-32.

Greenberg, J. 1993. The social side of fairness: Interpersonal and informational classes of organizational justice. In R. Cropanzano (Ed), Series in applied psychology. Justice in 
the workplace: Approaching fairness in human resource management: 79-103. Hillsdale, NJ: Lawrence Erlbaum Associates.

Gross, N., Mason, W. S., \& McEachern, A. W. 1958. Explorations in role analysis: Studies of the school superintendency role. New York: Wiley.

Gupta, A., Briscoe, F., \& Hambrick, D. C. 2017. Red, blue, and purple firms: Organizational political ideology and corporate social responsibility. Strategic Management Journal, 38(5): 1018-1040.

Gupta, A., Briscoe, F., \& Hambrick, D. C. 2018. Evenhandedness in resource allocation: Its relationship with CEO ideology, organizational discretion, and firm performance. Academy of Management Journal, 61(5): 1848-1868.

Hage, J. \& Marwell, G., 1968. Toward the development of an empirically based theory of role relationships. Sociometry, 31(2): 200-212.

Homburg, C., \& Bucerius, M. 2006. Is speed of integration really a success factor of mergers and acquisitions? An analysis of the role of internal and external relatedness. Strategic Management Journal, 27(4): 347-367.

Hromei, A. 2014. Non-financial factors that influence the success of a merger transaction. The Alpha Instit. For Multicultural Studies, ed. Proc. of Economy and Management: 4th Communication, Context, and Inter-disciplinarity Conf. 2014 (Petru Maior University Press, Tirgu)

Humphery-Jenner, M., Sautner, Z., \& Suchard, J. A. 2017. Cross-border mergers and acquisitions: The role of private equity firms. Strategic Management Journal, 38(8): 1688-1700.

Ireland, R. D., Hitt, M. A., \& Vaidyanath, D. 2002. Alliance management as a source of competitive advantage. Journal of Management, 28(3): 413-446.

Jensen, M. C., \& Meckling, W. H. 1976. Theory of the firm: Managerial behavior, agency costs and ownership structure. Journal of Financial Economics, 3(4): 305-360.

John, K., Knyazeva, A., \& Knyazeva, D. 2015. Employee rights and acquisitions. Journal of Financial Economics, 118(1): 49-69.

Jost, J. T. 2006. The end of the end of ideology. American Psychologist, 61(7): 651-670.

Jost, J. T., Federico, C. M., \& Napier, J. L. 2009. Political ideology: Its structure, functions, and elective affinities. Annual Review of Psychology, 60: 307-337.

Kahn, R. L., Wolfe, D. M., Quinn, R. P., Snoek, J. D., \& Rosenthal, R. A. 1964. Organizational stress: Studies in role conflict and ambiguity. New York: Wiley.

Kale, P., Singh, H., \& Perlmutter, H. 2000. Learning and protection of proprietary assets in strategic alliances: Building relational capital. Strategic Management Journal, 21(3): 217-237.

Katz, D., \& Kahn, R. L. 1966. The social psychology of organizations. New York: Wiley.

Katz, D., \& Kahn, R. L. 1978. The social psychology of organizations, rev. ed. New York: Wiley.

Khan, Z., Soundararajan, V., Wood, G., Ahammad, F.M. 2017. Employee emotional resilience during post-merger integration across national boundaries: Rewards and the mediating role of fairness norms. Journal of World Business, advance online publication $10 \mathrm{July.} \mathrm{http://dx.doi.org/10.1016/j.jwb.2017.06.009.}$

Khanna, T., Gulati, R., \& Nohria, N. 1998. The dynamics of learning alliances: Competition, cooperation, and relative scope. Strategic Management Journal, 19(3): 193-210.

Knight, A. P., Menges, J. I., \& Bruch, H. 2018. Organizational affective tone: A meso perspective on the origins and effects of consistent affect in organizations. Academy of Management Journal, 61(1): 191-219. 
Knorr, A., \& Arndt, A. 2003. Why did Walmart fail in Germany? Working paper no. 24, Institute for World Economics and International Management, University of Bremen, Bremen, Germany.

Korschun, D., Aggarwal, A., Rafieian, H., \& Swain, S. D. 2016. Taking a stand: Consumer responses to corporate political activism. https://ssrn.com/abstract=2806476. Accessed 28 November 2018.

Kostova, T. 1999. Transnational transfer of strategic organizational practices: A contextual perspective. Academy of Management Review, 24(2): 308-324.

Kostova, T., \& Roth, K. 2002. Adoption of an organizational practice by subsidiaries of multinational corporations: Institutional and relational effects. Academy of Management Journal, 45(1): 215-233.

Kostova, T., Roth, K., \& Dacin, M. T. 2008. Institutional theory in the study of multinational corporations: A critique and new directions. Academy of Management Review, 33(4): 994-1006.

Larsson, R., \& Finkelstein, S. 1999. Integrating strategic, organizational, and human resource perspectives on mergers and acquisitions: A case survey of synergy realization. Organization Science, 10(1): 1-26.

Luo, Y. 2007. The independent and interactive roles of procedural, distributive, and interactional justice in strategic alliances. Academy of Management Journal, 50(3): 644-664.

Marín, L., Cuestas, P. J., \& Román, S. 2016. Determinants of consumer attributions of corporate social responsibility. Journal of Business Ethics, 138(2): 47-260.

Markus, H., \& Zajonc, R. B. 1985. The cognitive perspective in social psychology. In G. Lindsey \& E. Aronson (Eds), Handbook of social psychology: 137-230. New York: Random House.

Martin, D., \&Wilson, J. 2005. Role theory. In G. Ritzer (Ed), Encyclopedia of social theory: 652-655. Thousand Oaks, CA: Sage Publications.

Marwell, G., \& Hage, J. 1970. The organization of role-relationships: A systematic description. American Sociological Review, 35(5): 884-900.

McIntyre, T. L. 2004. A model of levels of involvement and strategic roles of human resource development (HRD) professionals as facilitators of due diligence and the integration process. Human Resource Development Review, 3(2): 173-182.

Mead, G. H. 1934. Mind, self and society. Chicago: University of Chicago Press.

Melkonian, T., Monin, P., \& Noorderhaven, N. G. 2011. Distributive justice, procedural justice, exemplarity, and employees' willingness to cooperate in M\&A integration processes: An analysis of the Air France-KLM merger. Human Resource Management, 50(6): 809-837.

Meyer, J. W., \& Rowan, B. 1977. Institutionalized organizations: Formal structure as myth and ceremony. American Journal of Sociology, 83(2): 340-363.

Moreno, J. L. 1934. Who shall survive?: A new approach to the problem of human interrelations. Washington, DC: Nervous and Mental Disease Publishing.

Morrison, E. W., \& Robinson, S. L. 1997. When employees feel betrayed: A model of how psychological contract violation develops. Academy of Management Review, 22(1): 226-256.

Nahavandi, A., \& Malekzadeh, A. R. 1988. Acculturation in mergers and acquisitions. Academy of Management Review, 13(1): 79-90.

Olie, R. 1994. Shades of culture and institutions-in international mergers. Organization Studies, 15(3): 381-405. 
Orlandi, I., Shemla, M., \& Heugens, P. 2018. Showing boards' true colors: Using role theory as processual lenses to understand board behavior. Academy of Management Proceedings, (2018)1: 159-182.

Oxley, J. E. 1999. Institutional environment and the mechanisms of governance: the impact of intellectual property protection on the structure of inter-firm alliances. Journal of Economic Behavior \& Organization, 38(3): 283-309.

Papadakis, V. 2007. Growth through mergers and acquisitions: How it won't be a loser's game. Business Strategy Series, 8(1): 43-50.

Petrou, A., Chow, D., \& Procopiou, A. 2018. Labor rights belief mismatch and cross-border acquisitions: The role of organizational political ideology. Working paper, Cyprus University of Technology, Cyprus.

Petrou, A., Chow, D., Procopiou, A., \& Louca, C. 2018. Marriage to the Same Kind: Organizational Political Ideology and Mergers and Acquisitions. Working paper, Cyprus University of Technology, Cyprus.

Phillips, N., Tracey, P., \& Karra, N. 2009. Rethinking institutional distance: strengthening the tie between new institutional theory and international management. Strategic Organization, 7(3): 339-348.

Piekkari, R., Vaara, E., Tienari, J., \& Säntti, R. 2005. Integration or disintegration? Human resource implications of a common corporate language decision in a cross-border merger. The International Journal of Human Resource Management, 16(3): 330-344.

Platt, E., \& Fontanella, K. 2018. Global deals surge past \$1tn at fastest ever pace. Financial Times, March 22.

Powell, W. W., \& Rerup, C. 2017. Opening the black box: The microfoundations of institutions. In R. Greenwood, C. Oliver, T. B. Lawrence, \& R. E. Meyer (Eds), The Sage handbook of organizational institutionalism (2nd edition). Thousand Oaks: Sage.

Regnér, P., \& Edman, J. 2014. MNE institutional advantage: How subunits shape, transpose and evade host country institutions. Journal of International Business Studies, 45(3): 275-302.

Reus, T. H. 2012. Culture's consequences for emotional attending during cross-border acquisition implementation. Journal of World Business, 47(3): 342-351.

Risberg, A. 2001. Employee experiences of acquisition processes. Journal of World Business, 36(1): 58-84.

Robinson, S. L., \& Wolfe Morrison, E. 2000. The development of psychological contract breach and violation: A longitudinal study. Journal of Organizational Behavior, 21(5): 525-546.

Sales, A. L., \& Mirvis, P. H. 1984. When cultures collide: Issues of acquisition. In J. Kimberly \& R. E. Quinn (Eds), Managing organizational transitions: 107-133. Homewood: Irwin.

Schweizer, L. 2005. Organizational integration of acquired biotechnology companies into pharmaceutical companies: The need for a hybrid approach. Academy of Management Journal, 48(6): 1051-1074.

Seo, M. G., \& Hill, N. S. 2005. Understanding the human side of merger and acquisition: An integrative framework. The Journal of Applied Behavioral Science, 41(4): 422-443.

Shimizu, K., Hitt, M. A., Vaidyanath, D., \& Pisano, V. 2004. Theoretical foundations of cross-border mergers and acquisitions: A review of current research and recommendations for the future. Journal of International Management, 10(3): 307-353.

Sinkovics, R. R., Zagelmeyer, S., \& Kusstatscher, V. 2011. Between merger and syndrome: The intermediary role of emotions in four cross-border M\&As. International Business Review, 20(1): 27-47. 
Skarmeas, D., \& Leonidou, C. N. 2013. When consumers doubt, watch out! The role of CSR skepticism. Journal of Business Research, 66(10): 1831-1838.

Stahl, G. K., Chua, C. H., \& Pablo, A. L. 2012. Does national context affect target firm employees' trust in acquisitions?. Management International Review, 52(3): 395-423.

Stahl, G. K., \& Voigt, A. 2008. Do cultural differences matter in mergers and acquisitions? A tentative model and examination. Organization Science, 19(1): 160-176.

Stryker, S. 1987. The vitalization of symbolic interactionism. Social Psychology Quarterly, 50(1): 83-94.

Stryker, S. 1991. Exploring the relevance of social cognition for the relationship of self and society: Linking the cognitive perspective and identity theory. In J. A. Howard \& P. L. Callero (Eds), The self-society dynamic: Cognition, emotion, and action: 19-41. New York: Cambridge University Press.

Stryker, S., \& Statham, A. 1985. Symbolic interaction and role theory. In G. Lindsay \& E. Aronson (Eds), Handbook of social psychology (3rd ed., Vol. 1): 311-378. New York: Random House

Sutton, R. I. 1991. Maintaining norms about expressed emotions: The case of bill collectors. Administrative Science Quarterly, 36(2): 245-268.

Teerikangas, S., \& Very, P. 2006. The culture-performance relationship in M\&A: From yes/no to how. British Journal of Management, 17(S1): S31-S48.

Tetlock, P. E., Vieider, F. M., Patil, S. V., \& Grant, A. M. 2013. Accountability and ideology: When left looks right and right looks left. Organizational Behavior and Human Decision Processes, 122(1): 22-35.

Thibaut, J. W., \& Walker, L. 1975. Procedural justice: A psychological analysis. Hillsdale, NJ: Lawrence Erlbaum Associates.

Tyler, T., \& Bies, R. J. 1990. Beyond formal procedures: The interpersonal context of procedural justice. In J. Carroll (Ed), Applied social psychology and organizational settings: 77-98. Hillsdale, NJ: Lawrence Erlbaum Associates.

Uhlenbruck, K. 2004. Developing acquired foreign subsidiaries: the experience of MNE S in transition economies. Journal of International Business Studies, 35(2): 109-123.

Vaara, E. 2003. Post-acquisition integration as sensemaking: glimpses of ambiguity, confusion, hypocrisy, and politicization. Journal of Management Studies, 40(4): 859894.

Vaara, E., \& Monin, P. 2010. A recursive perspective on discursive legitimation and organizational action in mergers and acquisitions. Organization Science, 21(1): 3-22.

Vaara, E., Sarala, R., Stahl, G. K., \& Björkman, I. 2012. The impact of organizational and national cultural differences on social conflict and knowledge transfer in international acquisitions. Journal of Management Studies, 49(1): 1-27.

van Knippenberg, D., van Knippenberg, B., Monden, L., \& de Lima, F. 2002. Organizational identification after a merger: A social identity perspective. British Journal of Social Psychology, 41(2): 233-252.

Wagner, T., Lutz, R. J., \& Weitz, B. A. 2009. Corporate hypocrisy: Overcoming the threat of inconsistent corporate social responsibility perceptions. Journal of Marketing, 73(6): 77-91.

Walumbwa, F. O., Mayer, D. M., Wang, P., Wang, H., Workman, K., \& Christensen, A. L. 2011. Linking ethical leadership to employee performance: The roles of leader-member exchange, self-efficacy, and organizational identification. Organizational Behavior and Human Decision Processes, 115(2): 204-213.

Weick, K. E. 1995. Sensemaking in organizations (Vol. 3). Thousand Oaks, CA: Sage.

Weick, K. E., Sutcliffe, K. M., \& Obstfeld, D. 2005. Organizing and the process of sensemaking. Organization Science, 16(4): 409-421. 
Wu, Z., \& Salomon, R. 2017. Deconstructing the liability of foreignness: Regulatory enforcement actions against foreign banks. Journal of International Business Studies, 48(7): 837-861.

Younge, K.A., Tong, T.W., \& Fleming, L. 2015. How anticipated employee mobility affects acquisition likelihood: Evidence from a natural experiment. Strategic Management Journal, 36(5): 686-708.

Zaheer, S. 1995. Overcoming the liability of foreignness. Academy of Management Journal, 38(2): 341-363.

Zhao, H. A. O., Wayne, S. J., Glibkowski, B. C., \& Bravo, J. 2007. The impact of psychological contract breach on work-related outcomes: A meta-analysis. Personnel Psychology, 60(3): 647-680. 
